\title{
Mechanical Properties of Reactive Powder Concrete (RPC) with Mineral Admixture
}

\author{
Nuha H. Al-Jubory \\ Lecturer \\ College of Engg / Civil Engg. Dept. / University of Mosul
}

\begin{abstract}
Reactive powder concrete (RPC) is a special type of concrete, it is rather a mortar than an actual concrete mixture, because traditional coarse and fine aggregate are replaced by very fine sand with particle size in range of (150-400) $\mu \mathrm{m}$.

In the present experimental investigation, compressive strength, splitting tensile strength and flexural strength of plain reactive powder concrete and reactive powder concrete reinforced with $1 \%$ and $2 \%$ steel fiber are compared, by using local available material and curing in $20^{\circ} \mathrm{C}$ and $80^{\circ} \mathrm{C}$, and the experimental study was curried out on a two sets of samples. Each set consisted of $(54)$ cubes of $(50 \times 50 \times 50 \mathrm{~mm})$, (18) cylinder of $(100 \times 200 \mathrm{~mm})$ and $(18)$ prism of $(50 \times 50 \times 300 \mathrm{~mm})$. The results show that the maximum compressive strength is $74 \mathrm{MPa}$ with $2 \%$ steel fiber and curing in $20^{\circ} \mathrm{C}$. The addition of steel fiber by $1 \%$ and $2 \%$ increased the compressive strength, splitting tensile strength and flexural strength.
\end{abstract}

Keywords: reactive powder concrete, steel fibre, compressive strength, flexural strength, tensile strength

\footnotetext{
الخواص الميكاتيكية لخرسانة المسحوق الفعال باستخدام مضافات معدنية

نهم حميدي الجبوري

مدرس المدان

كلية الهندسة/قسم الهندسة المدنبة/ جامعة الموصل

الخلاصة الخنة

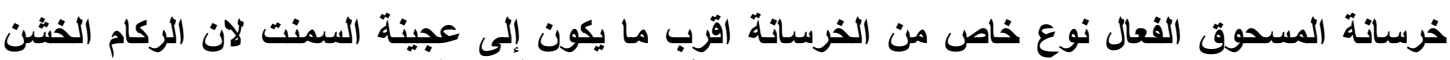

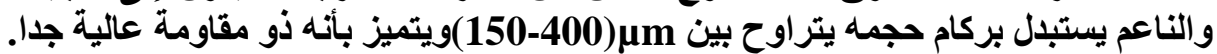

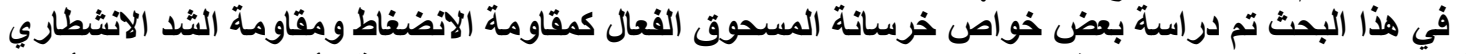

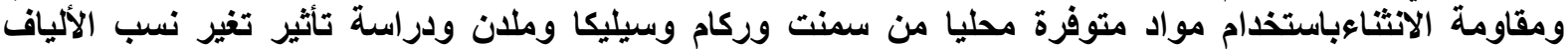

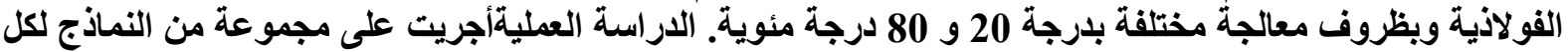

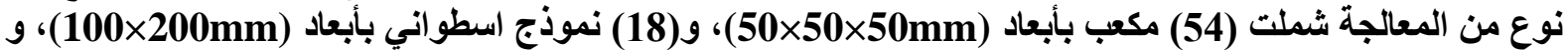

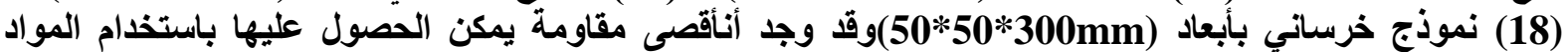
المحلية (74 MPa) عند إضافة 2\% 2 (ألياف فولاذية ومعالجة بدرجة 20 مئوية.
} 


\section{Introduction}

Beginning with Richard and Cherezy (1995), Jörg Jungwirth (2002), Chang. et al(2009) and Malik. et. al.(2010), [1,2,3 and 4] many researchers have investigated the various aspects of RPC. However, proper selection ofmaterials, their proportioning and process of production influence the rheological properties and mechanicalperformances of RPC.

The term Reactive Powder Concrete $(R P C)$ has been used to describe a fiberreinforced, superplasticized, silica fume - cement mixture with very low water-cement ratio $(w / c)$ characterized by the presence of very fine quartz sand $(0.15-0.40 \mathrm{~mm})$ instead of ordinary aggregate [5,6]. In fact, it is not a concrete because there is no coarse aggregate in the cement mixture. The absence of coarse aggregate was considered by the inventors to be a key-aspect for the microstructure and the performance of the $R P C[5,6]$ in order to reduce the heterogeneity between the cement matrix and the aggregate. However, due to theuse of very fine sand instead of ordinary aggregate, the cement content of the $R P C$ is as high as 900$1000 \mathrm{~kg} / \mathrm{m} 3$.

The influence of Portland cement and silica fume type on the performances of reactive powder concrete (RPC) mixtures have been studied, only by using $\mathrm{C}_{3} \mathrm{~A}$ - free Portland cement, in combination with a white silica fume brand. The w/c ratio was as low as 0.18 , and the compressive strength was as high as $200 \mathrm{MPa}$ at 3 day after a thermal treatment at $160{ }^{\circ} \mathrm{C}$. However a strong reduction in the early compressive strength was recorded. The replacement of the white silica fume by other silica fume types (grey or dark), as well as the substitution of the other Portland cements for the $\mathrm{C}_{3} \mathrm{~A}$-free Portland cement caused an increase in the w/c and a reduction in the compressive strength (110-160 MPa). However, with these mixtures there was no reduction in the early compressive strength.[7]

Compressive strength and flexural strength of plain reactive powder concrete (RPC) and RPC reinforced with corrugated steel fibres and recron $3 \mathrm{~s}$ fibres were investigated. Composition of RPC, which was optimized by trial and error method in previous work by varying different ingredient, was used with a water cement ratio of 0.22 . Corrugated steel fibres were used $0.4 \mathrm{~mm}$ dia. and $13 \mathrm{~mm}$ long and recron $3 \mathrm{~s}$ fiber of triangular shape and 12 $\mathrm{mm}$ length were incorporated in the concrete.[8]

\section{Purpose and Scope}

The purpose of this work is to study some mechanicalproperties of reactive powder concrete (RPC)including compressive, flexure,splitting tensile strength of plain reactive powder concrete and reactive powder concrete reinforced with $1 \%$ and $2 \%$ steel fiber, by using local available material and curing in $20^{\circ} \mathrm{C}$ and $80^{\circ} \mathrm{C}$.

\section{Materials:}

Cement:One type of cement was used, Ordinary Portland Cement, produced locally in accordance with Iraqi Specification (IQS:No5, 1984)[9].Thechemical and physical properties are given in table (1) and (2) respectively. 
Al-Jubory: Mechanical Properties of Reactive Powder Concrete (RPC) with

Table (1) : Chemical Composition of The O.P.C. Table (2) : Physical Properties of The O.P.C.

\begin{tabular}{|c|c|c|}
\hline Property & $\begin{array}{c}\text { Test result } \\
\text { (Percentage) }\end{array}$ & $\begin{array}{c}\text { Standard } \\
\text { IQS, No.5 }\end{array}$ \\
\hline \multicolumn{3}{|c|}{ 1.Oxide composition: } \\
\hline Alumina, $\mathrm{Al}_{2} \mathrm{O}_{3}$ & 5.6 & $3-8$ \\
\hline Silica, $\mathrm{SiO}_{2}$ & 21.52 & $17-25$ \\
\hline Ferric Oxide, $\mathrm{Fe}_{2} \mathrm{O}_{3}$ & 2.74 & $0.5-6$ \\
\hline Lime, $\mathrm{CaO}$ & 62.55 & $60-67$ \\
\hline $\begin{array}{c}\text { Sulphuric } \\
\text { Anhydride, } \mathrm{SO}_{3}\end{array}$ & 2.54 & Max. $2.8 \%$ \\
\hline Magnesia, $\mathrm{MgO}$ & 3.23 & Max. 5\% \\
\hline \multicolumn{3}{|c|}{ 2.Compound composition: } \\
\hline $\mathrm{C}_{3} \mathrm{~A}$ & 12.07 & $11.96-12.3$ \\
\hline $\mathrm{C}_{2} \mathrm{~S}$ & 34.20 & $28.61-37.9$ \\
\hline $\mathrm{C}_{3} \mathrm{~S}$ & 36.44 & $31.03-41.05$ \\
\hline $\mathrm{C}_{4} \mathrm{AF}$ & 7.98 & $7.72-8.02$ \\
\hline
\end{tabular}

\begin{tabular}{|c|c|c|}
\hline Property & Test result & $\begin{array}{c}\text { Standard } \\
\text { IQS, No.5 }\end{array}$ \\
\hline $\begin{array}{c}\text { Fineness(Residue } \\
\text { on sieve No. 170) }\end{array}$ & $2 \%$ & Max. 10\% \\
\hline $\begin{array}{c}\text { Specific surface } \\
\text { "Blaine"(cm } / \mathrm{gm})\end{array}$ & 3358.5 & Min. 2250 \\
\hline Initial setting time & 140 (min.) & 45 (min.) \\
\hline Final setting time & 385 (min.) & 600 (max.) \\
\hline Specific gravity & 3.14 & - \\
\hline $\begin{array}{c}\text { Compressive } \\
\text { strength(MPa) }\end{array}$ & & \\
\hline at 3 days & 19.22 & 16.0 (min.) \\
\hline at 7 days & 27.88 & 24.0 (min.) \\
\hline
\end{tabular}

\section{Fine aggregate:}

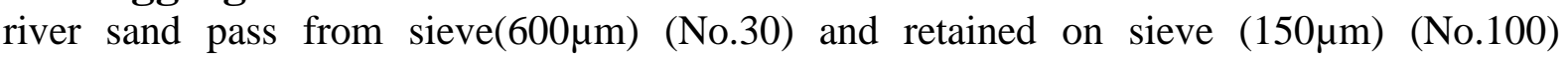
according to ASTM C 109/C 109M-02 [10].

\section{Mixing Water:}

Ordinary drinking (tap) water was used for concrete mixes.

\section{Silica fume:}

The Chemical and physical properties are given in tables (3) and (4).

Table (3) : Chemical Properties of Silica fume

\begin{tabular}{|c|c|c|}
\hline Property & Percentage & $\begin{array}{c}\text { Limit of ASTM } \\
\text { C1240-03a[11] }\end{array}$ \\
\hline $\begin{array}{c}\text { Silica, } \\
\mathrm{SiO}_{2}\end{array}$ & 95.95 & Min. 85.0\% \\
\hline $\begin{array}{c}\text { Sulphuric } \\
\text { Anhydride, } \\
\mathrm{SO}_{3}\end{array}$ & 0.22 & Max. 4.0\% \\
\hline
\end{tabular}

\section{Chemical Admixture:}

Hyperplast PC200 is a high performance super plasticizing admixture based on polycarboxylic. It can be used with all types of Portland cement to achieve highest concrete durability and performance.The main properties are shown in table (5).
Table (4) : Physical Properties of Silica fume

\begin{tabular}{|l|l|}
\hline $\begin{array}{c}\text { Particle size } \\
\text { (typical) }\end{array}$ & $\begin{array}{l}<1 \text { micron } \\
\text { Bulk density }\end{array}$ \\
& $\begin{array}{c}\text { As- produced }: 130 \text { to } 430 \\
\mathrm{~kg} / \mathrm{m}^{3}\end{array}$ \\
$\begin{array}{c}\text { Densified: } 480 \text { to } 720 \\
\mathrm{~kg} / \mathrm{m}^{3}\end{array}$ \\
\hline Specific gravity & 2.2 \\
\hline Specific surface & 15,000 to $30,000 \mathrm{~m}^{2} / \mathrm{kg}$ \\
\hline
\end{tabular}

Table (5): The Properties of HRWR

\begin{tabular}{|c|l|}
\hline Type & Polycarboxylic \\
\hline Name & Hyperplast PC200 \\
\hline Color & Light yellow liquid. \\
\hline Specific gravity & $1.05 \pm 0.02$ \\
\hline Dosage & $\begin{array}{c}(0.75-2.50) \text { liter per } 100 \mathrm{~kg} \\
\text { of cementitious. }\end{array}$ \\
\hline
\end{tabular}




\section{Mix Proportions}

The investigated mixes were prepared depended on the original mix of reactive powder concreter coined by the inventors Richard and Cheyrezy 1994 [12], the mix proportions by $\left(\mathrm{Kg} / \mathrm{m}^{3}\right)$ are shown in table (6)

\section{Curing:}

All sample were curing in two conditions a-Room temperature at $20^{\circ} \mathrm{C}$.

Table (6): The mix proportions

\begin{tabular}{|l|l|l|l|}
\hline Material $\left(\mathrm{Kg} / \mathrm{m}^{3}\right)$ & Mix 1 & Mix 2 & Mix 3 \\
\hline Cement & 955 & 955 & 955 \\
\hline Silica & 229 & 229 & 229 \\
\hline Fine sand $(150-600 \mu \mathrm{m})$ & 1051 & 1051 & 1051 \\
\hline Superplasticizer & 19 & 19 & 19 \\
\hline Steel fibers & 0 & 95.5 & 191 \\
\hline Water & 347 & 347 & 347 \\
\hline w/c & 0.36 & 0.36 & 0.36 \\
\hline w/(c+sf $)$ & 0.29 & 0.29 & 0.29 \\
\hline
\end{tabular}

\section{Discussions}

\section{Compressive Strength Test}

Compressive strength of concrete is the most useful and important property of concrete. Many other properties of concrete such as durability, resistance to shrinkage Young's modulus, imperviousness etc. are dependent on the compressive strength of concrete.

The purpose of the compression test is to determine the crushing strength of hardened concrete and is conducted on cube specimens of $50 \times 50 \times 50 \mathrm{~mm}$ size as the RPC does not contain coarseaggregate and maximum size of particle is $800 \mu$ maccording to ASTM C 109/C 109M-02 [10]. Here to determine the average compressive strength, three cubes of each concrete mix are tested after 3,7, and 28 days, testing under compression testing machine of 180tones capacity.

From table (7), Fig.(1) and Fig.(2), the compressive strength reach up to $74 \mathrm{MPa}$ for $2 \%$ fiber reinforced for $20^{\circ} \mathrm{C}$ curing. Curing in hot water $\left(80{ }^{\circ} \mathrm{C}\right)$ gives a compressive strength at 3 day equal to (80-90) \% of that of 28 day. The compressive strength at 7 day equal to (93-97)\% of that of 28 day. In $20{ }^{\circ} \mathrm{C}$ curing the compressive strength at 3 day equal to (57-65)\% of that of 28 day compressive strength and at 7 day equal to (75)\% of 28 day compressive strength.

Table (7): The compressive strength at different ages.

\begin{tabular}{|c|c|c|c|c|c|c|c|c|c|c|}
\hline \multirow{3}{*}{$\begin{array}{l}\text { Mix } \\
\text { No. }\end{array}$} & \multicolumn{10}{|c|}{ Compressive Strength (MPa) } \\
\hline & \multicolumn{5}{|c|}{ Curing at $20^{\circ} \mathrm{C}$} & \multicolumn{5}{|c|}{ Curing at $80^{\circ} \mathrm{C}$} \\
\hline & $\begin{array}{l}3 \\
\text { days }\end{array}$ & $\begin{array}{l}\% \text { of } \\
28 \text { days }\end{array}$ & $\begin{array}{l}7 \\
\text { days }\end{array}$ & $\begin{array}{l}\% \text { of } \\
28 \text { days }\end{array}$ & $\begin{array}{l}28 \\
\text { days }\end{array}$ & $\begin{array}{l}3 \\
\text { days }\end{array}$ & $\begin{array}{l}\% \text { of } \\
28 \text { days }\end{array}$ & $\begin{array}{l}7 \\
\text { days }\end{array}$ & $\begin{array}{l}\% \text { of } \\
28 \text { days }\end{array}$ & $\begin{array}{l}28 \\
\text { days }\end{array}$ \\
\hline 1 & 35.1 & 64.2 & 41.2 & 75.3 & 54.7 & 43.4 & 83.1 & 48.4 & 92.7 & 52.2 \\
\hline 2 & 38.5 & 57.8 & 50.0 & 75.1 & 66.6 & 52.0 & 81.9 & 59.2 & 93.2 & 63.5 \\
\hline 3 & 48.5 & 65.5 & 56.0 & 75.7 & 74.0 & 60.2 & 94.0 & 62.0 & 96.9 & 64.0 \\
\hline
\end{tabular}



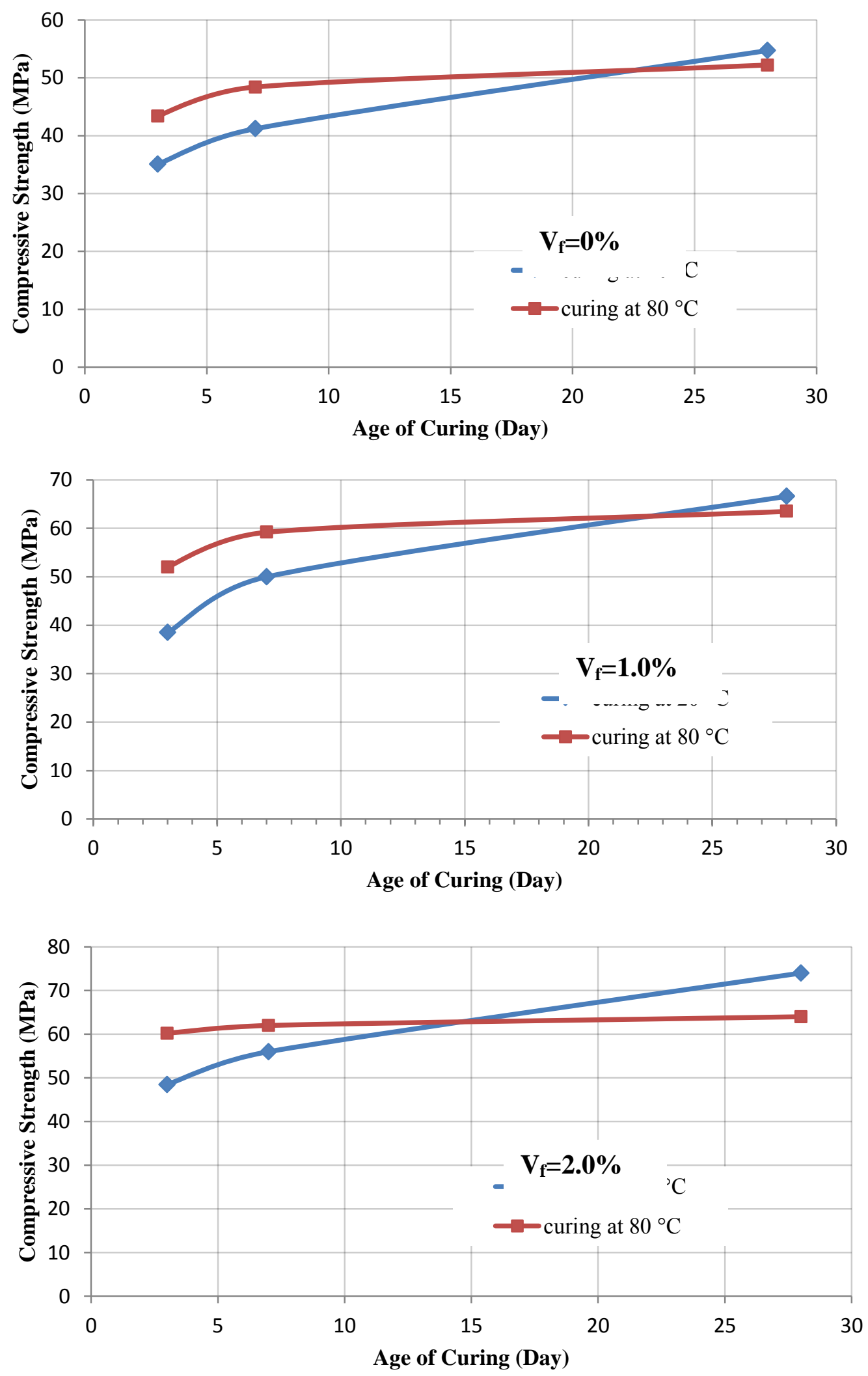

Fig.(1)The Relation between Cube Compressive Strength and Age of Curing 

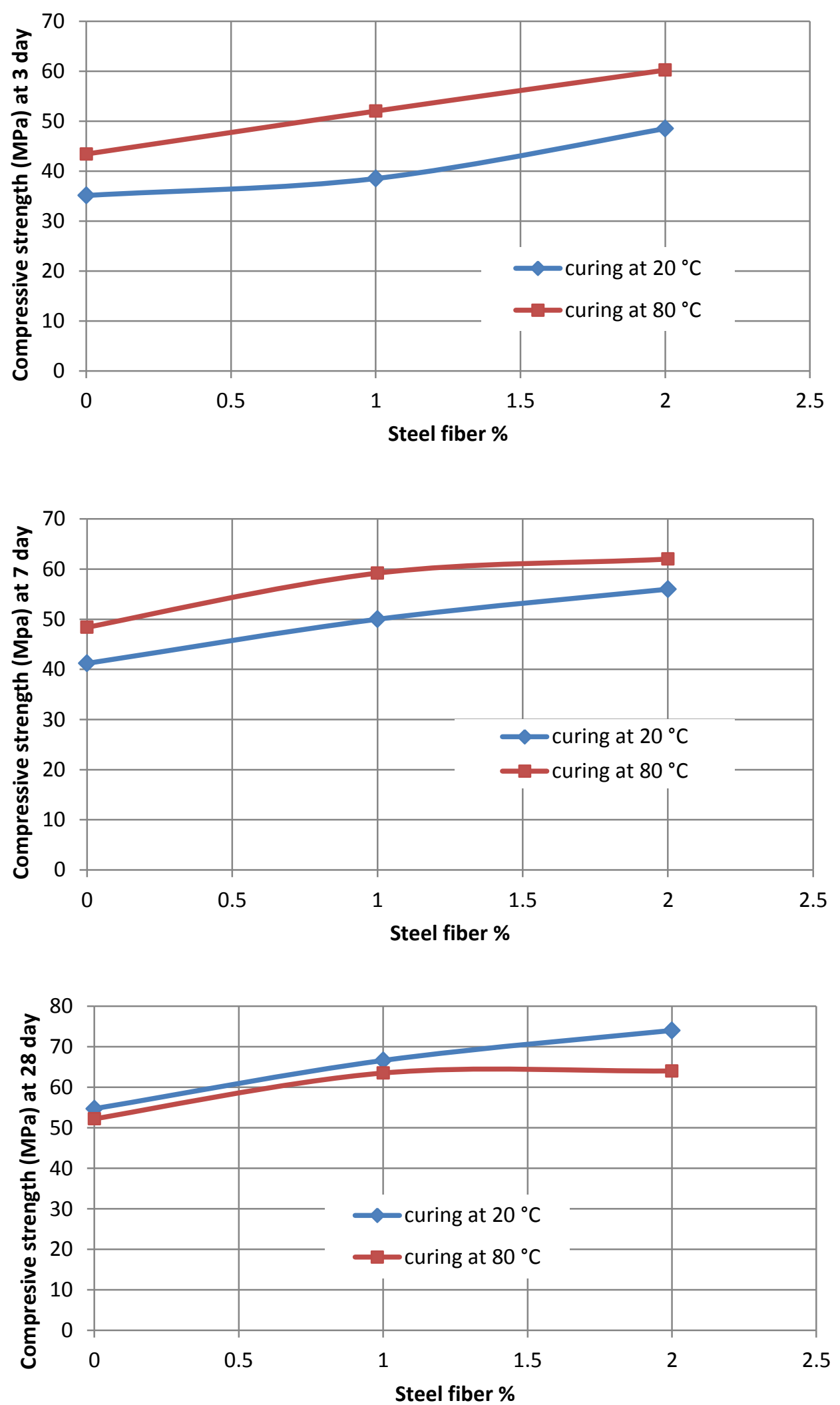

Fig.(2)The Relation between Cube Compressive Strength and percentageof steel fiber 


\section{Splitting Tensile Strength Test}

An indirect test of tensile strength of concrete has been standardized by ASTM C 49696 [13] and is in general use in this tests specimen of cylindrical shape of diameter $100 \mathrm{~mm}$ and $200 \mathrm{~mm}$ inlength are tested under a compressive load across the diameter along its length till the cylinder splits. To determine the average split tensile strength, in the present work, 3 cylinders of each mix are tested under compression testing machine of 180tones capacity after removing the specimens at the age of 28 days from the curing tank. Cylindrical specimen is placed in the machine, along its length, keeping plywood strip between the cylinder and the testing machine bearing surfaces at the top and bottom ofcylinder. Load is gradually applied and maximum load at which the specimen fails is noted. The magnitude of the tensile strength is worked out with the help of $2 \mathrm{P} / \pi \mathrm{LD}$. Where $\mathrm{P}$ is applied load at failure, $\mathrm{D}$ is the diameter in $\mathrm{mm}$ and $\mathrm{L}$ is the length of specimen in mm. Fig.(3) show the splitting failure of the tested specimen with $0 \%, 1 \%$ and $2 \%$ of steel fiber.

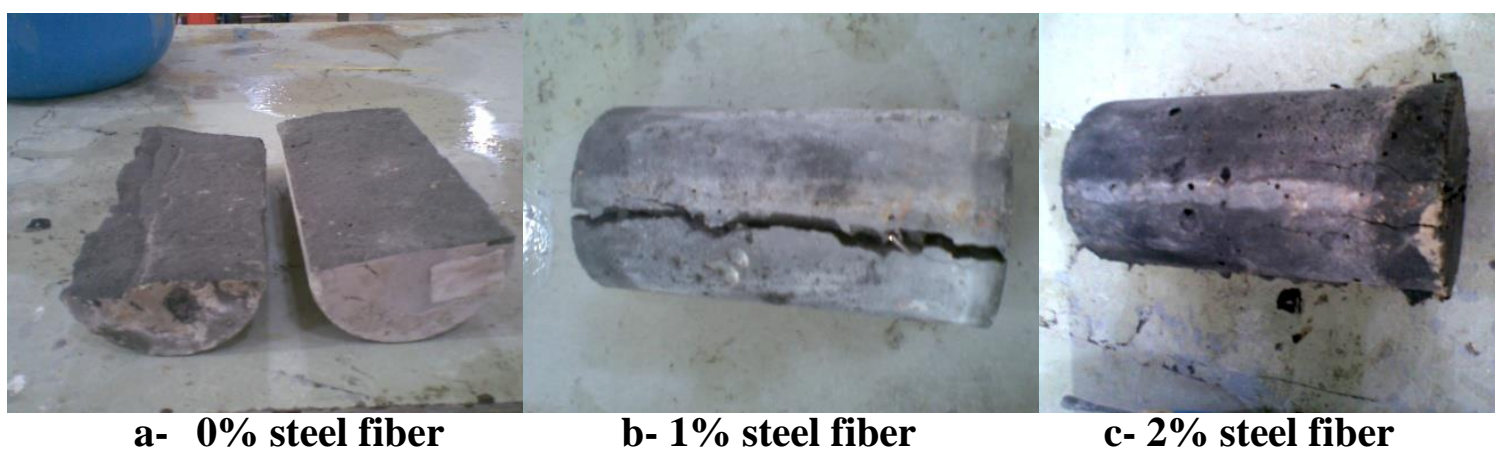

Fig.(3)The specimen after splitting test

Table (8) show the splitting tensile strength at 28 days and percentage of increase from mix (1), the addition of steel fiber $1 \%$ and $2 \%$ increased the splitting tensile strength by $17.56 \%$ and $25.32 \%$ respectively in curing in $20^{\circ} \mathrm{C}$, and increased it by $26.62 \%$ and $42.13 \%$ respectively in curing in $80^{\circ} \mathrm{C}$.

Table (8): The Splitting Tensile Strength at 28 days.

\begin{tabular}{|c|l|l|l|l|}
\hline \multirow{2}{*}{$\begin{array}{c}\text { Mix } \\
\text { No. }\end{array}$} & \multicolumn{4}{|l|}{ Splitting Tensile Strength(MPa) } \\
\cline { 2 - 5 } & $\begin{array}{c}\text { Curing at } \\
20^{\circ} \mathrm{C}\end{array}$ & $\begin{array}{c}\text { Percentage } \\
\text { of increase }\end{array}$ & $\begin{array}{c}\text { Curing at } \\
80^{\circ} \mathrm{C}\end{array}$ & $\begin{array}{c}\text { Percentage of } \\
\text { increase }\end{array}$ \\
\hline 1 & 5.41 & 0.0 & 4.77 & 0.0 \\
\hline 2 & 6.36 & $17.56 \%$ & 6.04 & $26.62 \%$ \\
\hline 3 & 6.78 & $25.32 \%$ & 6.78 & $42.13 \%$ \\
\hline
\end{tabular}

\section{Flexural Strength Test}

The purpose of flexural strength test is to have an idea of the load at which a concrete member in bending may crack due to Tension. It gives an idea of tensile strength of concrete. The tensile strength of concrete in bending is known as flexural tensile strength or modulus of rapture, and is equal to bending moment at failure divided by the section modulus of a beam under test.In the present work, beam samples of each mix casted of size 50x50x300 
$\mathrm{mm}$ in size are tested under simply supported condition keeping the span of $275 \mathrm{~mm}$ a third point load test is conducted on universal testing machine. The maximum load atwhich beam fails is recorded and flexural strength is calculated.

Table (9) show the Modulus of Rapture at 28 days and percentage of increase from mix (1), the addition of steel fiber $1 \%$ and $2 \%$ increased the flexural strength by $14.19 \%$ and $40.46 \%$ respectively in curing in $20^{\circ} \mathrm{C}$, and increased it by $11.9 \%$ and $45.47 \%$ respectively in curing in $80^{\circ} \mathrm{C}$.

Table (9): The Modulus of Rapture at 28 days.

\begin{tabular}{|c|c|c|c|c|}
\hline \multirow{2}{*}{$\begin{array}{l}\text { Mix } \\
\text { No. }\end{array}$} & \multicolumn{4}{|c|}{ Modulus of Rapture (Flexural Strength) (MPa) } \\
\hline & $\begin{array}{l}\text { Curing at } \\
20^{\circ} \mathrm{C}\end{array}$ & $\begin{array}{l}\text { Percentage } \\
\text { of increase }\end{array}$ & $\begin{array}{c}\text { Curing at } \\
80^{\circ} \mathrm{C}\end{array}$ & $\begin{array}{l}\text { Percentage of } \\
\text { increase }\end{array}$ \\
\hline 1 & 9.02 & 0.0 & 9.83 & 0.0 \\
\hline 2 & 10.30 & $14.19 \%$ & 11.0 & $11.9 \%$ \\
\hline 3 & 12.85 & $40.46 \%$ & 14.30 & $45.47 \%$ \\
\hline
\end{tabular}

\section{Mode of Failure}

Flexural specimen failed at plane approximately in the middle of the specimen. The addition of steel fiber gives a monition to failure by appearance of crack in the tension face of specimen before the failure happened, while the specimen without steel fiber failed suddenly. Fig.(4) show the flexure specimen after tested, at different fiber volume percentage.

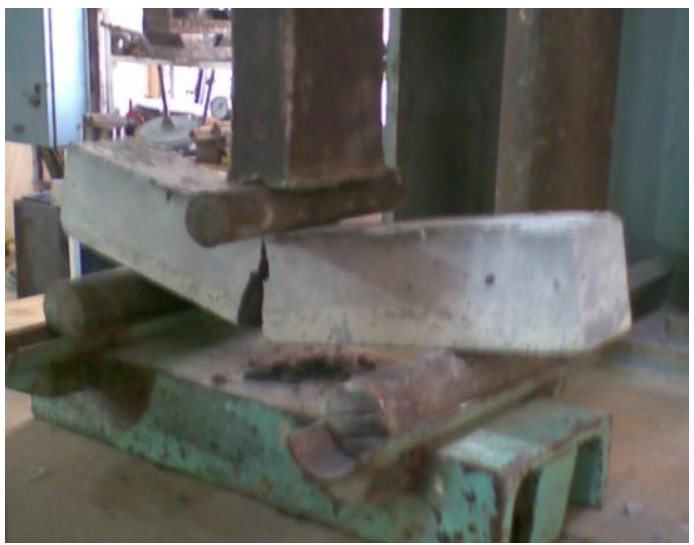

a-0\% steel fiber

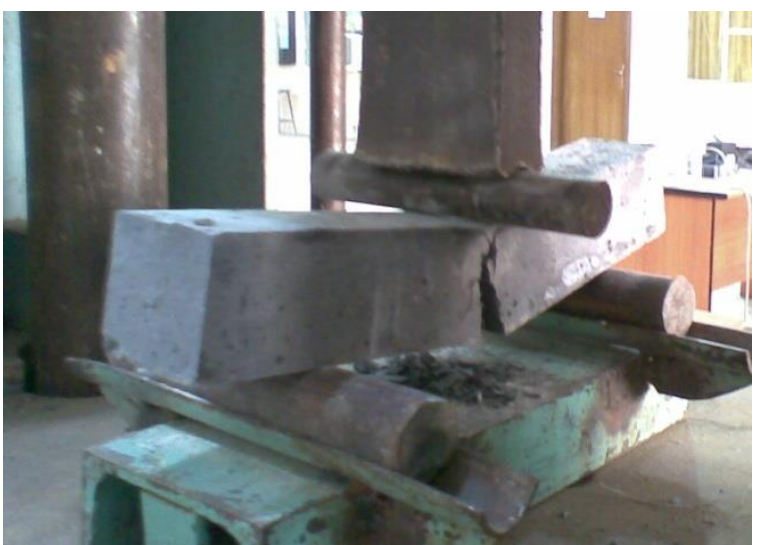

b- $1 \%$ steel fiber

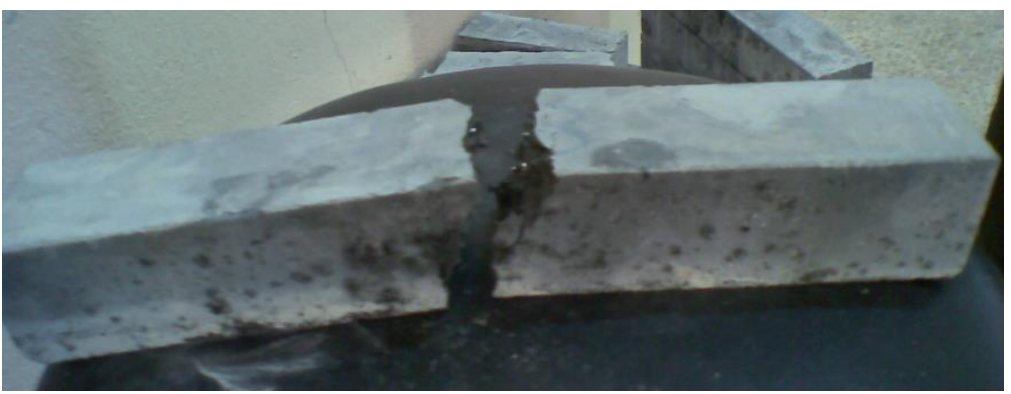

c- $2 \%$ steel fiber

Fig.(4)Mode of failure of flexure test 


\section{Conclusion}

1. The compressive strength reach up to $70 \mathrm{MPa}$, that equaled to $30 \%$ of compressive strength of RPC 200 of Richard and Cheyrezy [12]that is may be because of high percentage content of $\mathrm{C}_{3} \mathrm{~A}$ in local cement while RPC 200 have free $\mathrm{C}_{3} \mathrm{~A}$.

2. Addition of steel fibers does not affect the finishibility of reactive powder concrete.

3. Addition of steel fibers increased the compressive strength, flexural strength and splitting tensile strength.

4. Curing in high temperature water $80^{\circ} \mathrm{C}$ increased the compressive strength at early ages and decreased it at 28 day compare with curing in $20^{\circ} \mathrm{C}$.

5. Curing in hot water at $80{ }^{\circ} \mathrm{C}$ gives a compressive strength at 3 day equal to (80-90)\% of that of 28 day, and at 7 day equal to (93-97)\% of that of 28 day. compressive strength compare with curing in $20{ }^{\circ} \mathrm{C}$ gives a compressive strength at 3 day equal to (57-65)\% of 28 day compressive strength and at 7 day equal to (75)\% of 28 day compressive strength.

\section{References}

1. Richard p. and Cheyrezy M.H., "composition of reactive powder concrete", Cement and concrete research 25(7):pp.1501-1511, 1995.

2. Jungwirth J., "Underspanned Bridge Structures in Reactive Powder Concrete", 4th International PhD Symposium inCivil Engineering, Munich, Germany,2002.

3. Chang, T.P., Chen, B.T., Wang, J.J., and Wu, C.S., "Performance of RPC with Different Conditions and itsRetrofitting Effects on cxoncrete members", Proc., Concrete Repair, Rehabilitation and Retrofitting I, Ed. Alexander et al,Taylor and Francis Group, London, pp1203-1207, 2009.

4. Malik, Adnan R, Foster, and Stephen J., "Carbon Fibre Reinforced Polymer Confined Reactive Powder ConcreteColumns Experimental Investigation”,ACI Structural Journal, May 2010.

5. Richard, P. and Cheyrezy, M.H. "Reactive Powder Concretes with HighDuctility and 200-800 MPa Compressive Strength", Concrete Technology:Past, Present, and Future, Proceedings of the V. Mohan Malhotra Symposium,ACI SP-144, S. Francisco 1994, pp. 507-518. Editor: P.K. Mehta.

6. Coppola, L., Troli, R., Collepardi, S., Borsoi, A., Cerulli, T. and Collepardi,M. "Innovative Cementitious Materials. From HPC to RPC. Part II. TheEffect of Cement and Silica Fume Type on the Compressive Strength ofReactive Powder Concrete", L'IndustriaItaliana del Cemento, 707, 1996, pp112-125.

7. Coppola, L., Cerulli, T., Troli, R. and Collepardi, M. "The Influence of Raw Materials on Performance of Reactive Powder Concrete", InternationalConference on HighPerformance Concrete, and Performance and Quality ofConcrete Structures, Florianopolis, 1996, pp.502-513.

8. Maroliya, M.K. and Modhera, C.D. "A Comparative Study of Reactive Powder Concrete Containing Steel Fibers and Recron 3S Fibers", Journal of Engineering Research and Studies, Vol. I, Issue I, July-Sept. 2010, pp 83-89.

$$
\begin{aligned}
& \text { 9.المو اصفات القياسية العر اقية (رقم 5)، (1984)، ”خصائص السمنت البورتلانديالاعتيادي“،الجهاز المركزي } \\
& \text { للتقييس و السيطرة النوعية، العراق، } 1984 .
\end{aligned}
$$


10. ASTM C 109/C 109M-02 "Standard Test Method for CompressiveStrength of Hydraulic Cement Mortars Using 2-in. or 50-mm Cube Specimens".

11. ASTM C 1240-03a, "Standard Specification for Silica Fume Used in Cementitious Mixtures", 2003

12. Richard p. and Cheyrezy M.H., "Reactive Powder Concretes with High Ductility and 200-800 MPa Compressive Strength”, Concrete Technology Past, Present, and Future, ACI SP 144, editor: P.Kumar Mehta, S. Francisco, USA, 1994, pp 507-518.

13. ASTM C 496-96 "Standard Test Method for Splitting Tensile Strength of cylindrical Concrete Specimens", American Society for Testing and Materials.

The work was carried out at the college of Engineering. University of Mosul 